\title{
Oilseeds native to the Cerrado have fatty acid profile beneficial for cardiovascular health
}

\author{
Oleaginosas nativas do Cerrado apresentam \\ perfis de ácidos graxos favoráveis \\ à saúde cardiovascular
}

\author{
Aline Medeiros ALVES ${ }^{1}$ \\ Daniela Canuto FERNANDES² \\ Jullyana Freitas BORGES² \\ Amanda Goulart de Oliveira SOUSA ${ }^{3}$ \\ Maria Margareth Veloso NAVES ${ }^{1}$
}

\section{A B S T R A C T}

\section{Objective}

To assess and compare the fatty acid composition of edible seeds and a nut native to the Cerrado (Brazilian savannah) to that of traditional oilseeds.

\section{Methods}

Baru almonds, Cerrado cashew nuts, and pequi almonds were extracted from the fruits using appropriate equipment. All edible seeds and nuts were roasted, except for the Brazil nut. The sample lipids were extracted via cold pressing. The fatty acids were esterified, and the fatty acid esters were analyzed by gas chromatography.

\section{Results}

The native and traditional edible seeds and nuts contain mostly monounsaturated fatty acids (42.72 $\mathrm{g}$ to $63.44 \mathrm{~g} / 100 \mathrm{~g}$ ), except for the Brazil nut, which showed predominance of polyunsaturated fatty acids (45.48 g/100 g). Pequi almond had the highest saturated fatty acid content $(36.14 \mathrm{~g} / 100 \mathrm{~g})$. The fatty acids with the highest concentration were oleic and linoleic acids, and palmitic acid was also found in considerable concentration in the oilseeds studied. The Cerrado cashew nut and the traditional cashew nut have similar fatty acid profiles. As

\footnotetext{
1 Universidade Federal de Goiás, Faculdade de Nutrição, Laboratório de Nutrição Experimental. R. 227, Quadra 68, 74605080, Goiânia, GO, Brasil. Correspondência para/ Correspondence to: AM ALVES. E-mails: <amedeiros87@gmail.com> and <mmvnaves@gmail.com>.

2 Universidade Federal de Goiás, Escola de Agronomia e Engenharia de Alimentos, Programa de Pós-Graduação em Ciência e Tecnologia de Alimentos, Goiânia, GO, Brasil.

${ }^{3}$ Universidade Federal de Goiás, Faculdade de Nutrição, Programa de Pós-graduação em Nutrição e Saúde, Goiânia, GO, Brasil.
} 
for the ratio of $\omega-6$ to $\omega-3$, the baru almond showed the highest ratio, 9:1, which was the closest to the recommended intake of these fatty acids.

\section{Conclusion}

The fatty acid profile of the edible seeds and nuts native to the cerrado is similar to those of traditional oilseeds. We suggest the inclusion of native oilseeds in the diet aiming at reducing the risk of cardiovascular disease, especially the baru almond and the cerrado cashew nut, due to the fact they have high ratio of monounsaturated fatty acids to saturated fatty acids.

Keywords: Anacardium. Arachis hypogaea. Bertholletia excels. Caryocar brasiliense Camb. Dipteryx alata Vog.

\section{R E S U M O}

\section{Objetivo}

Avaliar a composição de nozes e sementes comestíveis nativas do cerrado, no que diz respeito aos ácidos graxos, e comparar com oleaginosas tradicionais.

\section{Métodos}

A amêndoa de baru, a castanha-de-caju-do-cerrado e a amêndoa de pequi foram extraídas dos frutos com equipamentos apropriados. Todas as nozes e sementes comestiveis foram torradas, exceto a castanha-do-brasil. Os lipídeos das amostras foram extraídos a frio, os ácidos graxos foram esterificados e os ésteres de ácidos graxos foram analisados por cromatografia gasosa.

\section{Resultados}

As nozes e sementes comestíveis tradicionais e nativas possuem, predominantemente, ácidos graxos monoinsaturados $(42,72 \mathrm{~g}$ a 63,44 g/100 g), exceto a castanha-do-brasil, que apresentou predominância de ácidos graxos poli-insaturados $(45,48 \mathrm{~g} / 100 \mathrm{~g})$. A amêndoa de pequi apresentou o maior teor de ácidos graxos saturados $(36,14 \mathrm{~g} / 100 \mathrm{~g})$. Os ácidos graxos encontrados em maior concentração nas oleaginosas foram o ácido oleico e o linoleico; o ácido palmítico foi também detectado em proporções consideráveis. O perfil de ácidos graxos da castanha-de-caju-do-cerrado é comparável ao da castanha-de-caju tradicional. Quanto à relação entre ácidos graxos $\omega-6$ e $\omega-3$, a amêndoa de baru apresentou o valor de 9:1, mais próximo ao recomendado para consumo.

\section{Conclusão}

O perfil de ácidos graxos das nozes e sementes comestiveis nativas do cerrado se assemelha ao das tradicionais. Sugere-se, portanto, a inclusão das oleaginosas nativas em planos alimentares que visem a redução do risco de doenças cardiovasculares, sobretudo a amêndoa de baru e a castanha-de-caju-do-cerrado, por suas elevadas concentrações de ácidos graxos monoinsaturados em relação aos ácidos graxos saturados.

Palavras-chave: Anacardium. Arachis hypogaea. Bertholletia excels. Caryocar brasiliense Camb. Dipteryx alata Vog.

\section{NTRODUCTION}

Nuts are dried fruits widely consumed worldwide and high valued for their sensory and nutritional attributes and health benefits. The most popular nuts are almond, Brazil nut, cashew nut, pistachio, hazelnut, macadamia, and walnut ${ }^{1}$. Cerrado cashew nut is the fruit of the cerrado cashew tree (Anacardium othonianum Rizz.) that belongs to the group of nuts but is still narrowly consumed, and its nutritional value is not well known.
Although edible seeds are not nuts in a botanical sense, they have nutritional characteristics similar to those of the nuts. An example is the peanut, an edible seed of a legume which have a thick and dry pericarp. Other examples of edible seeds are the baru almond and the pequi almond, seeds of the fruits of baru tree (Dipteryx alata Vog.) and pequi tree (Caryocar brasiliense Camb.) and native species of the Cerrado with great commercial and technological potential ${ }^{1,2}$. 
Edible seeds and nuts contain high levels of lipids and proteins and a good essential amino acid profile, although containing a slight deficiency of lysine, methionine, and cysteine ${ }^{1-3}$. They also have a considerably high contents of dietary fiber and minerals ${ }^{2,3}$. Furthermore, these oilseeds stand out due to their fatty acid profile,

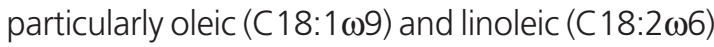
acids $^{4,5}$, and due to their high concentrations of phytosterols and phenolic compounds and high contents of vitamin $E^{6,7}$.

Regular consumption of edible seeds and nuts is recommended since it has been inversely associated with risk of cardiovascular diseases. Studies have confirmed the positive effects of edible seeds and nuts consumption on serum lipid profile and oxidative stress ${ }^{8-10}$. It has been found that the daily intake of $20 \mathrm{~g}$ of baru almond for 45 days, reduced serum concentrations of total cholesterol, Low Density Lipoproteincholesterol (LDL-C), and non-High Density Lipoproteincholesterol (non-HDL-c) in mildly hypercholesterolemic adults ${ }^{11}$. The benefits of oilseed consumption are primarily due to their fatty acid content and also to the synergistic interaction between fatty acids and bioactive compounds present in these foods. Considering the importance of monounsaturated and polyunsaturated fatty acids in reducing risk factors for cardiovascular disease, the aim of this study was to evaluate the fatty acid composition of edible seeds and nuts native to the Cerrado and compare it with the composition of oilseeds traditionally consumed in Brazil.

\section{METHODS}

The fruits of the baru tree (Dipteryx alata Vog.) were collected during the harvest season in the Western region of the Goiás state, between the cities of Jandaia and Paraúna. The fruits were placed on a flat surface in a single layer, kept away from light, and were stored at room temperature for 20 days. Subsequently, the woody endocarp was cracked open and the seeds were removed.
The Cerrado cashew fruits were collected in the Northeastern region of Goiás state. The Cerrado cashew nuts (Anacardium othonianum Rizz.) were extracted manually. The nuts were placed in a perforated aluminum sheet and heated under constant agitation until uniform browning and removal of the caustic liquid; the Cerrado cashew nuts were then decorticated.

The pequis (Caryocar Brasiliense Camb.) were acquired from the Centro de Abastecimento de Goiás (Ceasa, Fresh Fruit and Vegetable Supply Center of Goiás), and they came from three main pequi production and marketing regions (Minas Gerais, Tocantins, and Goiás). After reaching maturity, the pequi fruits were depulped and oven-dried at $60^{\circ} \mathrm{C}$ for $30 \mathrm{~h}$. The pequi almonds were removed using a nut cracking device ${ }^{2}$.

The peanut, cashew nut, and Brazil nut were purchased from local shops in the city of Goiânia (GO). The edible seeds and nuts were packed in low density polypropylene bags and stored under refrigeration until processing.

The baru and pequi almonds, cerrado cashew nut, and peanut were roasted in an electric oven to inactivate possible anti-nutritional factors. The baru almond and the peanut were roasted at $140^{\circ} \mathrm{C}$ for $30 \mathrm{~min}^{12}$; the pequi almond and the Cerrado cashew nut were roasted at $130^{\circ} \mathrm{C}$ for $30 \mathrm{~min}$. The cashew nut was acquired as unsalted roasted nut, whereas the Brazil nut was purchased as raw shelled nut, in order to assess the quality of this nut in natura since it is commonly consumed raw. Subsequently, the edible seeds and nuts were ground using a multiprocessor and sieved through a 60-mesh sieve for analysis.

The sample lipids were extracted using the Bligh-Dyer lipid extraction method ${ }^{13}$ and dried under nitrogen for two hours. The quantitative analysis of fatty acids was carried out according to Hartman \& Lago $^{14}$, by esterification of fatty acids. Esters of fatty acids were analyzed by gas chromatography using a Focus GC (ThermoFinnigan, Milan, Italy) equipped with a Flame Ionization Detector (FID) at $250^{\circ} \mathrm{C}$, split injector 
(2:98 ratio), and a RT-2560 capillary column (Restek Corporation, Bellefonte, PA, EUA), 100 $\mathrm{m}$ long, $0.25 \mathrm{~mm}$ internal diameter, and $0.2 \mathrm{~mm}$ film thickness of the liquid phase. Hydrogen was used as a carrier gas at a flow rate of $2 \mathrm{~mL} / \mathrm{min}$, and the makeup gases used to maintain the detector flame were nitrogen $(28 \mathrm{~mL} / \mathrm{min})$, hydrogen (30 mL/min), and synthetic air (300 mL/min). The volume of the sample injection was $1.0 \mu \mathrm{L}$ of sample. The integration of areas under the peaks was performed using the ChromQuest 4.1 version software (Thermo Fischer Scientific Brasil Instrumentos de Processo Ltda, São Paulo, SP). Identification and quantitation ( $\mathrm{g} / 100 \mathrm{~g}$ total lipids) of the fatty acids in the samples were performed using a calibration curve constructed from fatty acid methyl ester standards (Sigma-Aldrich, Saint Louis, MO, United Station of America).

All samples were analyzed in duplicate, and the results were subjected to variance analysis. The means were compared by the Tukey's test at the $5 \%$ level of significance. Statistical analysis was performed using Statistica software.

\section{RE S U L T S}

The total lipid content of the native and traditional edible seeds and nuts was high and almost similar among the samples, except for the Brazil nut, which showed the highest total lipid content (Table 1). The contents of palmitic, stearic, oleic, and linoleic acids, and the total contents of saturated, monounsaturated, and polyunsaturated fatty acids were significantly different between the samples (Table 1).

With regard to the total saturated fatty acids (Table 1), the pequi almond and Brazil nut showed concentrations higher than those of the other edible seeds and nuts. Palmitic acid (C16:0) was the most abundant saturated fatty acid in the samples, except for the cerrado cashew nut. Stearic acid (C18:0) was also detected in all samples but in smaller amounts, except for the cerrado cashew nut.
All native and traditional edible seeds and nuts, with the exception of the Brazil nut, contain predominantly monounsaturated fatty acids (Table 1). Baru almond, Cerrado cashew nut, and the traditional cashew nut showed more than 50\% of monounsaturated fatty acids. The fatty acid profile of the cerrado cashew nut was found to be comparable to that of the traditional cashew nut (Table 1), an unprecedented result in the literature. Oleic acid (C18:1 $\omega 9)$, known as $\omega-9$, was the most abundant monounsaturated fatty acid in these foods.

Brazil nut had the highest concentration of polyunsaturated fatty acids, followed by the

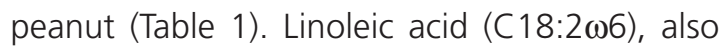
known as $\omega-6$, was the predominant polyunsaturated fatty acid in all edible seeds and nuts analyzed, except for the pequi almond.

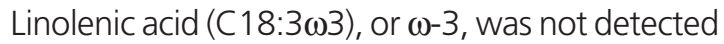
in the Brazil nut, but it was found in small amounts in all other samples (Table 1).

The $\omega-6$ to $\omega-3$ ratio varied considerably among the oilseeds studied. With regard to the native oilseeds, the highest monounsaturated to saturated fatty acid ratio was found in the baru almond, and among the traditional oilseeds, the cashew nut had the highest ratio. Besides, the baru almond showed the highest unsaturated to saturated fatty acid ratio (Table 1).

\section{DISCUSSION}

Edible seeds and nuts are an excellent source of energy due to their high lipid contents (more than 40\%) (Table 1). Brazil nut stands out with almost $60 \%$ lipids, whereas the other nuts contain approximately $45 \%$ lipids. This finding is consistent with that found by other authors in different nuts $1,4,5,10$.

Pequi almond and Brazil nut stand out due to their high contents of total saturated fatty acids (Table 1). In a study on the pequi (Caryocar brasiliense, Camb.) from the state of Piauí, Brazil15, the total saturated fatty acids of the almond was 
Table 1. Total lipid content ( $\mathrm{g} / 100 \mathrm{~g}$ of food) and fatty acid composition ( $\mathrm{g} / 100 \mathrm{~g}$ total lipids) of Cerrado native and traditional edible seeds and nuts.

\begin{tabular}{|c|c|c|c|c|c|c|c|c|c|c|c|c|}
\hline \multirow{3}{*}{ Constituent } & \multicolumn{6}{|c|}{ Seeds and nut native to Cerrado } & \multicolumn{6}{|c|}{ Traditional seed and nuts } \\
\hline & \multicolumn{2}{|c|}{ Baru almond } & \multicolumn{2}{|c|}{ Pequi almond } & \multicolumn{2}{|c|}{$\begin{array}{c}\text { Cerrado } \\
\text { cashew nut }\end{array}$} & \multicolumn{2}{|c|}{ Peanut } & \multicolumn{2}{|c|}{ Brazil Nut } & \multicolumn{2}{|c|}{ Cashew nut } \\
\hline & M & SD & M & SD & M & SD & M & SD & M & SD & M & SD \\
\hline Total Lipids & $42.69^{d}$ & 1.69 & $46.19^{\mathbf{b}, c}$ & 0.15 & $46.97^{b}$ & 0.75 & $44.04^{c, d}$ & 0.52 & $57.94^{\mathrm{a}}$ & 0.72 & $44.10^{c, d}$ & 0.33 \\
\hline \multicolumn{13}{|l|}{ Fatty acids } \\
\hline C10:0 & \multicolumn{2}{|c|}{ ND } & 0.03 & 0.00 & 0.03 & 0.00 & \multicolumn{2}{|c|}{ ND } & \multicolumn{2}{|c|}{ ND } & \multicolumn{2}{|c|}{ ND } \\
\hline C11:0 & \multicolumn{2}{|c|}{ ND } & 0.03 & 0.00 & 0.03 & 0.00 & \multicolumn{2}{|c|}{ ND } & \multicolumn{2}{|c|}{ ND } & \multicolumn{2}{|c|}{ ND } \\
\hline C14:0 & \multicolumn{2}{|c|}{ ND } & 0.34 & 0.00 & \multicolumn{2}{|c|}{ ND } & \multicolumn{2}{|c|}{ ND } & \multicolumn{2}{|c|}{ ND } & \multicolumn{2}{|c|}{ ND } \\
\hline C 16:0 & $7.16^{f}$ & 0.01 & $32.55^{\mathrm{a}}$ & 0.01 & $10.08^{d}$ & 0.11 & $12.41^{\mathrm{c}}$ & 0.04 & $15.60^{\mathbf{b}}$ & 0.03 & $9.27^{\mathrm{e}}$ & 0.01 \\
\hline C17:0 & 0.06 & 0.02 & 0.71 & 0.01 & 0.26 & 0.00 & \multicolumn{2}{|c|}{ ND } & 0.07 & 0.00 & \multicolumn{2}{|c|}{ ND } \\
\hline C18:0 & $4.97^{d}$ & 0.00 & $2.39^{f}$ & 0.01 & $11.54^{\mathrm{a}}$ & 0.22 & $2.92^{\mathrm{e}}$ & 0.02 & $9.74^{b}$ & 0.04 & $6.87^{c}$ & 0.02 \\
\hline C20:0 & 0.86 & 0.01 & & & & & 1.26 & 0.03 & 0.18 & 0.01 & 0.48 & 0.02 \\
\hline$C 21: 0$ & N & & 0.10 & 0.00 & 0.20 & 0.00 & N & & $\mathrm{NL}$ & & N & \\
\hline$C 22: 0$ & 0.51 & 0.00 & N & & 0.02 & 0.00 & 2.78 & 0.00 & 0.08 & 0.00 & 0.09 & 0.01 \\
\hline C24:0 & 1.90 & 0.00 & & & & & $N$ & & $\mathrm{NL}$ & & N & \\
\hline Total SFA & $15.47^{f}$ & 0.04 & $36.14^{\mathrm{a}}$ & 0.00 & $22.16^{\mathrm{c}}$ & 0.11 & $19.37^{d}$ & 0.03 & $25.67^{b}$ & 0.00 & $16.71^{\mathrm{a}}$ & 0.04 \\
\hline $\mathrm{C} 14: 1 \omega 5$ & N & & N & & 0.05 & 0.00 & N & & $\mathrm{N}$ & & & \\
\hline C $15: 1 \omega 5$ & N & & 0.03 & 0.00 & 0.01 & 0.00 & N & & N & & & \\
\hline$C 16: 1 \omega 7$ & 0.11 & 0.00 & 0.02 & 0.00 & 0.04 & 0.00 & 0.93 & 0.01 & 0.59 & 0.07 & 0.14 & 0.01 \\
\hline$C 17: 1 \omega 7$ & N & & 0.09 & 0.01 & 0.14 & 0.00 & N & & N & & & \\
\hline C $18: 1 \omega 9$ & $51.45^{c}$ & 0.03 & $44.76^{d}$ & 1.00 & $60.68^{b}$ & 0.21 & $41.03^{e}$ & 0.05 & $27.86^{f}$ & 0.02 & $63.11^{\mathrm{a}}$ & 0.04 \\
\hline$C 20: 1 \omega 9$ & N & & $\mathrm{N}$ & & & & 0.76 & 0.03 & $N$ & & 0.20 & 0.00 \\
\hline$C 24: 1 \omega 9$ & N & & 0.11 & 0.03 & & & N & & $\mathrm{N}$ & & N & \\
\hline Total MUFA & $51.57^{c}$ & 0.03 & $45.01^{d}$ & 1.04 & $60.92^{\mathbf{b}}$ & 0.21 & $42.72^{\mathrm{e}}$ & 0.06 & $28.45^{f}$ & 0.09 & $63.44^{\mathrm{a}}$ & 0.03 \\
\hline 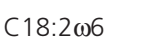 & $28.57^{c}$ & 0.01 & & & $0.03^{e}$ & 0.00 & $36.26^{\mathbf{b}}$ & 0.07 & $45.48^{\mathrm{a}}$ & 0.00 & $18.65^{d}$ & 0.01 \\
\hline $\mathrm{C} 18: 3 \omega 3$ & 3.14 & 0.01 & 5.97 & 0.02 & 1.09 & 0.01 & 1.50 & 0.01 & $\mathrm{~N}$ & & 0.20 & 0.01 \\
\hline$C 20: 2 \omega 6$ & & & 0.06 & 0.00 & & & & & N & & & \\
\hline$C 20: 3 \omega 6$ & N & & 0.44 & 0.05 & & & & & N & & & \\
\hline$C 20: 5 \omega 3$ & N & & 4.05 & 0.52 & 0.33 & 0.07 & & & N & & & \\
\hline$C 22: 2 \omega 6$ & N & & 0.02 & 0.00 & 0.03 & 0.00 & & & N & & & \\
\hline$C 22: 6 \omega 3$ & N & & 0.14 & 0.02 & 0.02 & 0.00 & & & $\mathrm{~N}$ & & & \\
\hline Total PUFA & $31.71^{c}$ & 0.01 & $10.68^{e}$ & 0.48 & $1.50^{f}$ & 0.08 & $37.76^{\mathbf{b}}$ & 0.09 & $45.48^{a}$ & $0.00^{\mathrm{a}}$ & $18.84^{d}$ & 0.02 \\
\hline Ratios & & & & & & & & & & & & \\
\hline$\omega 6 / \omega 3$ & 9.1 & & & & & & 24 & & & & & \\
\hline MUFA/SFA & 3.3 & & 1. & & & & & 21 & 1. & & & 30 \\
\hline UFA/SFA & 5.3 & & 1. & & & & & 15 & 2. & & & 32 \\
\hline
\end{tabular}

Note: ${ }^{a-f}$ Values followed by the same lowercase superscript letter in a row are not significantly different (Tukey's test, $p<0.05$ ).

ND: Not Detected; SFA: Saturated Fatty Acids; MUFA: Monounsaturated Fatty Acids; PUFA: Polyunsaturated Fatty Acids; UFA: Unsaturated Fatty Acids; M: Mean; SD: Standard Deviation.

higher (47.17 $\mathrm{g} / 100 \mathrm{~g}$ total lipids) than that found in the present study. In addition to the variety of climatic and soil conditions in the regions where the pequi tree is found, being a native plant which is not yet a commercial crop, there is a great variability in the physical and chemical properties of their fruits, which may explain the difference observed. Venkatachalam \& Sathe ${ }^{5}$ found the total saturated fatty acids concentration of
$25.35 \mathrm{~g} / 100 \mathrm{~g}$ of total lipids, a value very close to that found in the present study for Brazil nut. Despite the fact that saturated fatty acids play vital roles in lipid-storing cells, they are often associated with increased risk of cardiovascular diseases.

With regard to the total monounsaturated fatty acids, our results are close to values reported in the literature for the cashew nut, $61.68 \mathrm{~g} / 100 \mathrm{~g}^{5}$, 
and the pequi almond, $46.24 \mathrm{~g} / 100 \mathrm{~g}^{15}$. The content of monounsaturated fatty acids of the baru almond analyzed in the present study is higher than that found by Togashi \& Sgarbieri16, $44.5 \mathrm{~g} / 100 \mathrm{~g}$. This difference may be related to several factors, such as genetic and environmental variations; therefore, it deserves further studies on the characterization of this fruit according to the region of origin. Investigating different peanut cultivars, Sebei et al..$^{17}$ found total monounsaturated fatty acid values lower than those observed in this study, ranging from 31.31 to $38.79 \mathrm{~g} / 100 \mathrm{~g}$. Oleic acid content found in the cerrado cashew nut was similar to that of traditional cashew nut and close to that of olive oil (from 61.77 to $74.90 \mathrm{~g} / 100 \mathrm{~g})^{18}$, which is the main dietary source of this fatty acid.

Monounsaturated fatty acids are associated with lower risk of obesity, insulin resistance, and skin diseases ${ }^{19}$. Some studies have shown that the consumption of monounsaturated fatty acids, especially oleic acid can reduce serum triglycerides and LDL-C, and increase serum HDL-C concentrations and it can also decrease platelet aggregation and regulate insulin sensitivity ${ }^{20,21}$.

The predominance of polyunsaturated fatty acids in the Brazil nut, approximately $50 \%$, was also observed in other studies ${ }^{5,10}$. It is worth adding that the tendency of polyunsaturated fatty acids to undergo oxidation is higher than that of monounsaturated fatty acids; thus, the Brazil nut is more vulnerable to oxidation. The significant content of linoleic acid and reduced content of linolenic acid in edible seeds and nuts were consistent with data reported in the literature ${ }^{4,5,15}$.

Polyunsaturated fatty acids are produced by enzymes called desaturases and are associated with protection against cardiovascular diseases, diabetes, and allergies. They are also extremely important for cognitive development ${ }^{19}$. Linoleic and linolenic acids must be consumed in the diet since they cannot be synthesized by humans. They are precursors of long-chain polyunsaturated fatty acids, also called Essential Fatty Acids (EFA), such as Arachidonic Acid (AA), Eicosapentaenoic Acid
(EPA), and Docosahexaenoic Acid (DHA). Essential fatty acids play a significant role in important cellular functions, for example membrane integrity and fluidity, synthesis of eicosanoid such as prostaglandins, and regulation of blood pressure and mineral metabolism²1.

The $\omega-6$ to $\omega-3$ ratio should be considered because it contributes to the reduction of risk factors for cardiovascular diseases. According to the Institute of Medicine ${ }^{22}$, the recommended intake ratio of $\omega 6$ to $\omega 3$ fatty acids is approximately 10:1. The $\omega 6: \omega 3$ ratio in baru almond was the closest to the recommended intake of these fatty acids. Furthermore, this almond showed the highest monounsaturated to saturated fatty acid ratio compared to other native oilseeds evaluated. High monounsaturated to saturated fatty acid ratio has also been associated with reduced risk of cardiovascular diseases ${ }^{23}$.

In summary, the fatty acid profile of the baru almond is similar to that of the peanut, but it is more balanced and more beneficial to our health. Cerrado cashew nut has fatty acid profile comparable to that of the traditional cashew nut, and pequi almond and Brazil nut have similar fatty acid profiles. Therefore, the edible seeds and nut native to the Cerrado are alternative sources of high quality vegetable lipid, especially baru almond and Cerrado cashew nut, due to their high monounsaturated to saturated fatty acid ratio.

Fernandes et al. ${ }^{10}$ assessed the effects of consumption of baru almond and Brazil nut on hyperlipidemia and oxidative stress in rats and found that these oilseeds have great potential for human dietary use aimed at the prevention and control of dyslipidemia, and the best results were obtained with the baru almond. In another study with rats, it was also observed that the regular intake of the baru almond can protect tissues against iron-induced oxidative stress ${ }^{24}$. In obese individuals, it was found that daily consumption of Brazil nut improves selenium status and serum lipid profile, especially that of the high density 
lipoprotein, reducing the cardiovascular risk ${ }^{9}$. Moreover, in a study with mildly hypercholesterolemic individuals, Bento et al. ${ }^{11}$ showed that the daily supplementation of the baru almond improves serum lipid parameters and suggested that it can be included in the diet to reduce the risk of cardiovascular diseases.

Given the positive impact of oilseeds on the serum lipid profile and their nutritional attributes, such as large amounts of high-quality protein, dietary fiber, and minerals such as zinc², in vivo studies are suggested in order to investigate the effect of native oilseeds consumption on the control of cardiovascular diseases. Furthermore, additional studies are needed to increase productivity and market availability of oilseeds native to the Cerrado.

\section{CONCLUSION}

The fatty acid profile of the Cerrado cashew nut is similar to that of the traditional cashew nut. The fatty acids with the highest concentration in the native and traditional edible seeds and nuts studied were oleic and linoleic acids, followed by palmitic acid. Further investigations on the effects of native oilseeds consumption on human health and disease prevention are recommended, especially the baru almond and Cerrado cashew nut, since the consumption of foods high in monounsaturated fatty acids and low in saturated fatty acids have been associated with reduced risk of cardiovascular diseases.

\section{ACKNOWLEDGEMENTS}

The authors gratefully acknowledge the financial support provided by the Conselho Nacional de Desenvolvimento Científico e Tecnológico and the research scholarship granted by Coordenação de Aperfeiçoamento de Pessoal de Nivel Superior. They would also like to thank Prof. Dr. Moacir Evandro Lage for the fatty acid analyses.

\section{CONTRIBUTIONS}

AM ALVES, DC FERNANDES, JF BORGES, and AGO SOUSA contributed to the conception and design of this study, data collection and analysis, and manuscript writing. MMV NAVES coordinated and supervised the study and contributed to the drafting and critical revision of the manuscript.

\section{REFERENCES}

1. Freitas JB, Naves MMV. Composição química de nozes e sementes comestíveis e sua relação com a nutrição e saúde. Rev Nutr. 2010; 23(2):269-79. http://dx.doi.org/10.1590/S1415-527320100002 00010

2. Sousa AGO, Fernandes DC, Alves AM, Freitas JB, Naves MMV. Nutritional quality and protein value of exotic almonds and nut from Brazilian Savanna compared to peanut. Food Res Int. 2011; 44(7):2319-25. http://dx.doi.org/10.1016/j. foodres.2011.02.013

3. Freitas JB, Fernandes DC, Czeder LP, Lima JCR, Sousa AGO, Naves MMV. Edible seeds and nuts grown in Brazil as sources of protein for human nutrition. Food Nutr Sci. 2012; 3(6):857-62. http://dx.doi.org/ 10.4236/fns.2012.36114

4. Ros E, Mataix J. Fatty acid composition of nuts: implications for cardiovascular health. Br J Nutr. 2006; 96(Suppl. 2):S29-S35. http://dx.doi.org/10. 1017/BJN20061861

5. Venkatachalam M, Sathe SK. Chemical composition of selected edible nut seeds. J Agric Food Chem. 2006; 54(13):4705-14. http://dx.doi.org/10.1021/jf 0606959

6. Costa PA, Ballus CA, Teixeira-Filho J, Godoy HT. Phytosterols and tocopherols content of pulps and nuts of Brazilian fruits. Food Res Int. 2010; 43(6):1603-6. http://dx.doi.org/10.1016/j.foodres. 2010.04.025

7. Kornsteiner M, Wagner KH, Elmadfa I. Tocopherols and total phenolics in 10 different nut types. Food Chem. 2006; 98(2):381-7. http://dx.doi.org/10. 1016/j.foodchem.2005.07.033

8. Berryman $C E$, Grieger JA, West SG, Chen $C Y$, Blumber JB, Rothblat $\mathrm{GH}$, et al. Acute consumption of walnuts and walnut components differentially affect postprandial lipemia, endothelial function, oxidative stress, and cholesterol efflux in humans with mild hypercholesterolemia. J Nutr. 2013; 143(6):788-94. http://dx.doi.org/10.3945/jn.112. 170993 
9. Cominetti C, Bortoli MC, Garrido Jr AB, Cozzolino SMF. Brazilian nut consumption improves selenium status and glutathione peroxidase activity and reduces atherogenic risk in obese women. Nutr Res. 2012; 32(6):403-7. http://dx.doi.org/10.1016/j. nutres.2012.05.005

10. Fernandes DC, Alves AM, Castro GSF, Jordão Junior AA, Naves MMV. Effects baru almond and Brazil nut against hyperlipidemia and oxidative stress in vivo. J Food Res. 2015; 4(4):38-46. http://dx.doi. org/10.5539/jfr.v4n4p38

11. Bento APN, Cominetti C, Simões Filho A, Naves MMV. Baru almond improves lipid profile in mildly hypercholesterolemic subjects: A randomized, controlled, crossover study. Nutr Metab Cardiovasc Dis. 2014; 24(12):1330-6. http://dx.doi.org/10. 1016/j.numecd.2014.07.002

12. Fernandes DC, Freitas JB, Czeder LP, Naves MMV. Nutritional composition and protein value of the baru (Dipteryx alata Vog.) almond from the Brazilian Savanna. J Sci Food Agric. 2010; 90(10):1650-5. http://dx.doi.org/10.1002/jsfa.3997

13. Bligh EG, Dyer WJ. A rapid method of total lipid extraction and purification. Can J Biochem Physiol. 1959; 37(8):911-17. http://dx.doi.org/10.1139/ 059-099

14. Hartman L, Lago RCA. Rapid preparation of fatty acids methyl esters. Lab Pract. 1973; 22(6):475-6.

15. Lima A, Silva AMO, Trindade RA, Torres RP, ManciniFilho J. Composição química e compostos bioativos presentes na polpa e na amêndoa de pequi (Caryocar brasiliense Camb.). Rev Bras Frutic. 2007; 29(3):695-8. http://dx.doi.org/10.1590/S0100-29 452007000300052

16. Togashi M, Sgarbieri VC. Caracterização química parcial do fruto do baru (Dipteryx alata, Vog.). Ciênc Tecnol Aliment. 1994; 14(1):85-95.

17. Sebei K, Gnouma A, Herchi W, Sakouhi F, Boukhchina S. Lipids, proteins, phenolic composition, antioxidant and antibacterial activities of seeds of peanuts (Arachis hypogaea I) cultivated in Tunisia. Biol Res. 2013; 46(3):257-63. http://dx.doi.org/10. 4067/S0716-97602013000300006
18. Noorali M, Barzegar M, Sahari MA. Sterol and fatty acid compositions of olive oil as an indicator of cultivar and growing area. J Am Oil Chem Soc. 2014. http://dx.doi.org/10.1007/s11746-014-24 $97-z$

19. Lee H, Park WJ. Unsaturated fatty acids, desaturases, and human health. J Med Food. 2014; 17(2):189-97. http://dx.doi.org/10.1089/jmf.201 3.2917

20. Egert S, Kratz M, Kannenberg F, Fobker M, Wahrburg U. Effects of high-fat and low-fat dietsrich in monounsaturated fatty acids on serum lipids, LDL size and indices of lipid peroxidation in healthy non-obese men and women when consumed under controlled conditions. Eur J Nutr. 2011; 50(1):71-9. http://dx.doi.org/10.1007/s00 394-010-0116-9

21. Tvrzicka E, Kremmyda LS, Stankova B, Zak A. Fatty acids as biocompounds: Their role in human metabolism, health and disease: A review. Part 1: classification, dietary sources and biological functions. Biomed Pap Med Fac Univ Palacky Olomouc Czech Repub. 2011; 155(2):117-30.

22. Institute of Medicine. Dietary Reference Intakes: Recommended intakes for individuals. [cited: 30 July 2014]. Available from: http://www.iom.edu/ Activities/Nutrition/SummaryDRIs/ /media/Files/ Activity \%20/Files/Nutrition/DRIs/5_Summary \% 20Table\%20Tables\%201-4.pdf

23. Souza RGM, Gomes AC, Naves MMV, Mota JF. Nuts and legume seeds for cardiovascular risk reduction: Scientific evidence and mechanisms of action. Nutr Rev. 2015; 73(6):335-47. http://dx.doi.org/10.10 93/nutrit/nuu008

24. Siqueira EMA, Marin AMF, Cunha MSB, Fustinoni MA, Sant'Ana LP, Arruda SF. Consumption of baru seeds (Dipteryx alata Vog.), a Brazilian savanna nut, prevents iron-induced oxidative stress in rats. Food Res Int. 2012; 45(1):427-33. http://dx.doi.org/10. 1016/j.foodres.2011.11.005 